\title{
Role of osteopontin and its regulation in pancreatic islet
}

\author{
Cai, Mengyin
}

2018-01-01

Cai , M , Bompada , P , Salehi , A, Acosta , J R, Prasad , R B , Atac , D , Laakso , M , Groop , L \& De Marinis , Y 2018 , ' Role of osteopontin and its regulation in pancreatic islet ' , Biochemical and Biophysical Research Communications , vol. 495 , no. 1 , pp. 1426-1431 . https://doi.org/10.1016/j.

http://hdl.handle.net/10138/299382

https://doi.org/10.1016/j.bbrc.2017.11.147

publishedVersion

Downloaded from Helda, University of Helsinki institutional repository.

This is an electronic reprint of the original article.

This reprint may differ from the original in pagination and typographic detail.

Please cite the original version. 


\title{
Role of osteopontin and its regulation in pancreatic islet
}

\author{
Mengyin Cai a, b, Pradeep Bompada a ${ }^{\text {albert Salehi }}{ }^{\mathrm{c}}$, Juan R. Acosta ${ }^{\mathrm{a}}$, Rashmi B. Prasad ${ }^{\mathrm{a}}$, \\ David Atac ${ }^{\mathrm{a}}$, Markku Laakso ${ }^{\mathrm{d}}$, Leif Groop ${ }^{\mathrm{a}, \mathrm{e}}$, Yang De Marinis ${ }^{\mathrm{a},}{ }^{*}$ \\ a Diabetes and Endocrinology, Department of Clinical Sciences, University Hospital Malmö, Lund University, Malmö, Sweden \\ b Department of Endocrinology, The Third Affiliated Hospital of Sun Yat-Sen University, Guangzhou, China \\ ${ }^{\mathrm{c}}$ Division of Islet Cell Physiology, Department of Clinical Science, Lund University, Malmö, Sweden \\ ${ }^{\mathrm{d}}$ Institute of Clinical Medicine, Internal Medicine, University of Eastern Finland and Kuopio University Hospital, Kuopio, Finland \\ e Finnish Institute for Molecular Medicine (FIMM), Helsinki University, Helsinki, Finland
}

\section{A R T I C L E I N F O}

\section{Article history}

Received 17 November 2017

Accepted 22 November 2017

Available online 24 November 2017

\section{Keywords:}

Osteopontin

Diabetes

Hyperglycemia

Islets

Insulin

Incretins

\begin{abstract}
A B S T R A C T
Osteopontin (OPN) is involved in various physiological processes and also implicated in multiple pathological states. It has been suggested that OPN may have a role in type 2 diabetes (T2D) by protecting pancreatic islets and interaction with incretins. However, the regulation and function of OPN in islets, especially in humans, remains largely unexplored. In this study, we performed our investigations on both diabetic mouse model SUR1-E1506K $+/+$ and islets from human donors. We demonstrated that OPN protein, secretion and gene expression was elevated in the diabetic SUR1-E1506K+/+ islets. We also showed that high glucose and incretins simultaneously stimulated islet OPN secretion. In islets from human cadaver donors, OPN gene expression was elevated in diabetic islets, and externally added OPN significantly increased glucose-stimulated insulin secretion (GSIS) from diabetic but not normal glycemic donors. The increase in GSIS by OPN in diabetic human islets was $\mathrm{Ca}^{2+}$ dependent, which was abolished by $\mathrm{Ca}^{2+}$-channel inhibitor isradipine. Furthermore, we also confirmed that OPN promoted cell metabolic activity when challenged by high glucose. These observations provided evidence on the protective role of OPN in pancreatic islets under diabetic condition, and may point to novel therapeutic targets for islet protection in T2D.
\end{abstract}

(C) 2017 Elsevier Inc. All rights reserved.

\section{Introduction}

Osteopontin (OPN), also known as secreted phosphoprotein 1 (SPP1), is a multifunctional protein distributed in many tissues and body fluids [1]. It is involved in various physiological processes such as bone metabolism, tissue remodeling, and cell signaling including proliferation and migration. Besides physiological functions, OPN is also implicated in multiple pathological states, such as cancer [2], obesity [3] and atherosclerosis [4].

Circulating OPN is elevated in patients with type 2 diabetes (T2D) $[5,6]$; and studies supported the view that OPN is a key

\footnotetext{
Abbreviations: OPN, Osteopontin; SPP1, secreted phosphoprotein 1; T2D, type 2 diabetes; GIP, glucose-dependent insulinotropic polypeptide; WT, wild-type; GSIS, glucose-stimulated insulin secretion; iOPN, intracellular OPN; sOPN, secreted OPN; STZ, streptozotocin.

* Corresponding author. Lund University Diabetes Centre, CRC 91-12, Jan Waldenströms gata 35, 20502, Malmo, Sweden.

E-mail address: yang.de_marinis@med.lu.se (Y. De Marinis).
}

component of adipose tissue inflammation and insulin resistance $[7,8]$. There is emerging evidence suggesting a protective role of OPN in pancreatic islets and interaction with the incretin hormone glucose-dependent insulinotropic polypeptide (GIP) [9]. Studies including our own have shown that OPN prevented apoptosis and stimulated proliferation in islets and insulin-producing cells [9-11]. In pancreatic beta cells challenged by cytokine, OPN restored glucose-stimulated insulin secretion [9]. OPN was also shown to improve glucose-stimulated insulin secretion in diabetic rats with mild hyperglycemia [10]. Nevertheless, the regulation and function of OPN in islets, especially in humans, remains largely unexplored.

The aims of the present work were to study regulation of OPN gene expression, protein secretion, and the role of OPN in pancreatic islets under physiological and diabetic conditions. We performed our investigations in diabetic mouse model SUR1$\mathrm{E} 1506 \mathrm{~K}+/+$, as well as in pancreatic islets from non-diabetic and diabetic human cadaver donors. We show that OPN gene expression and secretion is highly sensitive to elevated glucose levels and 
incretins, and that OPN increased insulin secretion in human islets from diabetic donors. We also confirm a protective role of OPN in human islets by promoting cell metabolic activity when challenged by high glucose.

\section{Materials and methods}

\subsection{Diabetic mouse model}

The Sur1-E1506K+/+ mice have a knock-in mutation equivalent to the human mutation (E1506K) in the SUR1 (ABCC8) gene as previously described [12]. The mice were backcrossed $(n=8)$ into C57BL6 background [13,14]. Age-matched wild type littermates were used as controls. Our previous investigations have shown that Sur1-E1506K+/+ mice develop hyperglycemia from week 8 [15,16]. All protocols were approved by the local ethics review board at Lund University and the Malmö/Lund Animal Care and Use Committee.

\subsection{Immunostaining}

The pancreas from Sur1-E1506K+/+ mice and wild-type (WT) littermates were formalin fixed and paraffin embedded. OPN immunostaining was performed using 1:1000 anti-OPN antibody (AKm2A1, Santa Cruz Biotechnology, sc-21742, Dallas, Texas, United States), detected by PowerVision Homo-mouse Poly-HRP-Histostaining Kit (KDM-7AEC, Leica, Wetzlar, Germany) and DAB substrate kit (ab64238, Abcam, Cambridge, United Kingdom).

\section{3. $m R N A$ extraction and quantitative $R T-P C R$}

Mouse and human islet mRNA was extracted using RNeasy kit (QIAGEN, Venlo, Limburg, Netherlands) according to the manufacturer's instructions. RNA $(1.5 \mu \mathrm{g})$ was reverse transcribed to cDNA using the first strand cDNA synthesis kit (Fermentas, Massachusetts, USA). mRNA expression was assessed by quantitative RT-PCR performed on a Prism 7900 Sequence Detection System by Taqman assay (Applied Biosystems, Foster City, California, United States). The assay numbers for mouse are: Gapdh Mm99999915_g1; Ppib Mm00478295_m1; Spp1 Mm00436767_m1. The assay numbers for human are: HPRT1 Hs02800695_m1; PPIB Hs00168719_m1; SPP1 Hs00959010_m1.

\subsection{RNA sequencing}

Total RNA was extracted from islets, fat, liver and muscles of cadaver human donors and RNA-seq libraries were prepared using TruSeq RNA sample preparation kit standard protocols (Illumina, San Diego, California, United States). Libraries were then sequenced on an Illumina HiSeq 2000 using paired-end chemistry and 100-bp cycles to an average depth of $32 \mathrm{M}$ read pairs/sample. Reads were aligned to hg19 using STAR (version 2.4) and read count calculated by HTSeq-count and normalized using trimmed mean of M-values. Statistical inference for RNA-seq data was performed using the Rpackage 'limma'. Isoform abundances were calculated using RSEM (version 1.2.18).

\subsection{Islet insulin and OPN secretion assay}

Human islets were pre-incubated for $30 \mathrm{~min}$ at $37^{\circ} \mathrm{C}$ in a $\mathrm{KRB}$ buffer (pH 7.4) consisting of $120 \mathrm{mmol} / 1 \mathrm{NaCl}, 25 \mathrm{mmol} / \mathrm{l} \mathrm{NaHCO}$, $4.7 \mathrm{mmol} / \mathrm{l} \mathrm{KCl}, 1.2 \mathrm{mmol} / \mathrm{l} \mathrm{MgSO}$, $2.5 \mathrm{mmol} / \mathrm{l} \mathrm{CaCl}_{2}, 1.2 \mathrm{mmol} / \mathrm{l}$ $\mathrm{KH}_{2} \mathrm{PO}_{4}, 1 \mathrm{mmol} / \mathrm{l}$ glucose, $10 \mathrm{mmol} / \mathrm{l} \mathrm{HEPES}$ at $\mathrm{pH} 7.4$ and $1 \mathrm{mg} / \mathrm{ml}$ BSA. The medium was gassed with $95 \% \mathrm{O}_{2}$ and $5 \% \mathrm{CO}_{2}$ to obtain constant $\mathrm{pH}$ and oxygenation. Groups of twelve islets were incubated for $60 \mathrm{~min}$ at $37^{\circ} \mathrm{C}$ in $1 \mathrm{ml} \mathrm{KRB}$ buffer supplemented as indicated. Immediately after incubation, an aliquot of the medium was removed to determine insulin secretion by radioimmunoassay (RIA).

For OPN secretion assay, freshly isolated mouse islets were incubated using the same procedure. Culture medium from mouse islet incubation was then collected, and OPN secretion was measurement by ELISA according to the instructions from the manufacturer (Mouse Osteopontin ELISA, Cat. JP27351, IBL, Hamburg, Germany).

\subsection{Assessment of cell metabolic activity}

Pancreatic beta cell metabolic activity was measured by CellTiter 96 AQueous One Solution Cell Proliferation Assay Reagent (Promega, Stockholm, Sweden) according to the manufacturer's instructions. After a culture period of $24 \mathrm{~h}$ at 5 or $20 \mathrm{mmol} / \mathrm{l}$, the dispersed beta cells were washed three times with fresh culture medium. Thereafter, the cells were incubated for $2 \mathrm{~h}$ in CellTiter 96 Aqueous One Solution Reagent before measuring absorbance at $490 \mathrm{~nm}$ with a 96-well plate reader.

\subsection{Statistics}

Data are expressed as the mean \pm SEM. Statistical comparisons were performed using 2-tailed Student's t-test if not stated otherwise. Differences in human tissue gene expression were calculated using GLM model implemented in edgeR after log-transforming tested CPM normalization. Differences with $p<0.05$ were considered statistically significant.

\section{Results}

\subsection{Increased OPN protein expression, secretion and gene} expression in diabetic mouse islets

Our previous investigations have shown that the diabetic mouse model SUR1-E1506K+/+ displays hyperglycemia as early as 8 weeks of age. By week 12-16, the SUR1-E1506K+/+ mice had well established hyperglycemia and reduced plasma insulin levels [15]. In the pancreatic islets of 12-week-old diabetic SUR1-E1506K+/+ mice, we observed highly elevated OPN protein expression when compared to their wild-type (WT) littermates identified by immunohistochemistry staining (Fig. 1A-B). We also detected increased OPN secretion measured by ELISA (Fig. 1C); and elevated OPN (Spp1) gene expression by qPCR (Fig. 1D) from isolated SUR1E1506K+/+ islets compared to WT.

\subsection{Increased OPN secretion in mouse islet in response to high glucose and incretins}

To investigate if elevated OPN secretion in diabetic mouse islets is due to elevated blood glucose levels and if incretins have a putative role, we incubated isolated islets from normal glycemic WT mice in normal $(5 \mathrm{mM})$ or high $(16.7 \mathrm{mM})$ glucose in the presence and absence of GIP (100 nM) and GLP-1 (100 nM) for $1 \mathrm{~h}$. Similar to the observation of increased OPN secretion in diabetic islets, we observed a 3-fold increase in OPN secretion in high glucose-treated WT mouse islets. Both GIP and GLP-1 increased OPN secretion which was significant for GIP at $5 \mathrm{mM}$ glucose, and for GLP-1at 16.7 mM glucose (Fig. 2). 
A

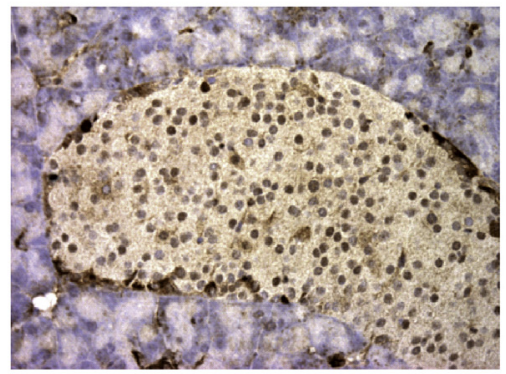

C

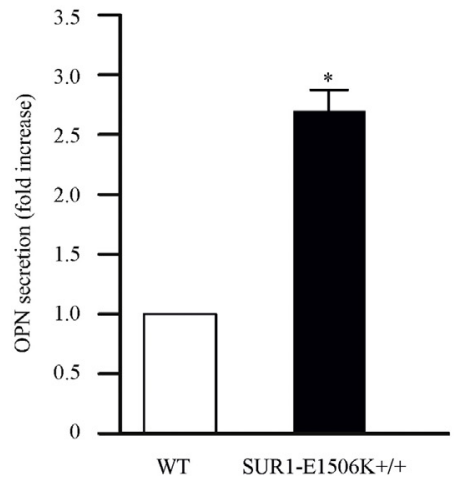

B

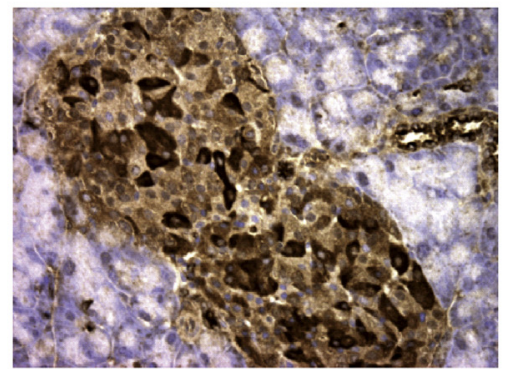

D

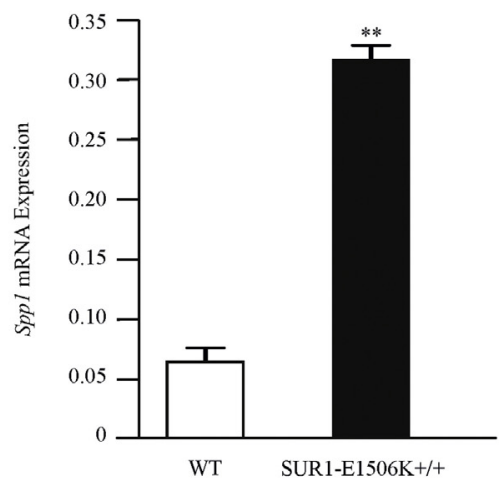

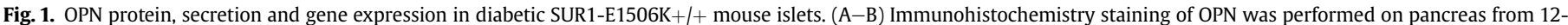

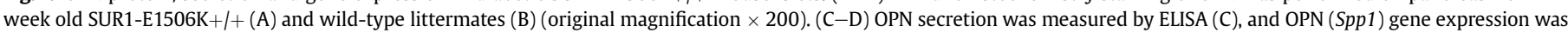

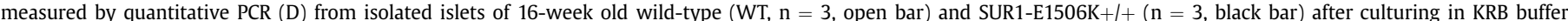
containing $5 \mathrm{mM}$ glucose for $1 \mathrm{~h}$. Data are the mean \pm SEM of three experiments from three WT and three mutant mice, respectively. ${ }^{*} p<0.05$, ${ }^{* *} p<0.01 \mathrm{vs}$ WT.

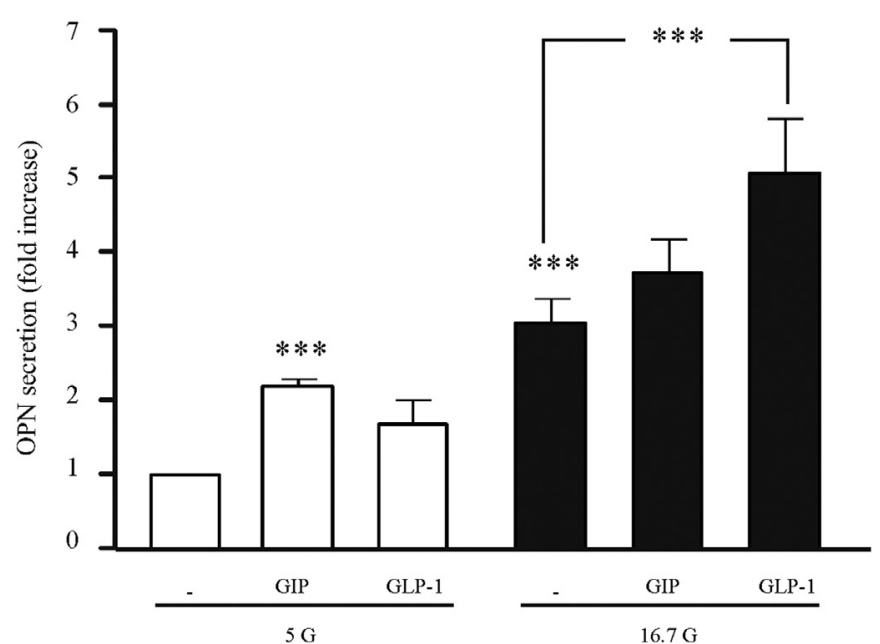

Fig. 2. Effect of glucose and incretins on OPN secretion from mouse islets. Islets from WT C57Bl mice were cultured in KRB buffer containing 5 or $16.7 \mathrm{mM}$ glucose in the presence or absence of GIP (100 nM) or GLP-1 (100 nM) for $1 \mathrm{~h}$. OPN secretion was measured by ELISA from the culture medium. ${ }^{*} p<0.05$ vs WT and ${ }^{* * *} p<0.001$ vs. $5 \mathrm{G}$ or as indicated. Data are the mean \pm SEM of five to eight experiments.

\subsection{Increased islet OPN (SPP1) gene expression in response to high glucose in humans}

In humans, SPP1 mRNA expression was higher in islets than in fat, liver and muscles (Fig. 3A). To study the correlation between islet SPP1 expression and HbA1c levels, we performed quantitative
PCR on islets from donors of non-diabetic (ND), T2D with $\mathrm{HbA} 1 \mathrm{c}<6.0 \%$ ( $42 \mathrm{mmol} / \mathrm{mol}$ ), and T2D with $\mathrm{HbA} 1 \mathrm{c}>6.5 \%$ (48 mmol/ mol) (Fig. 3B). SPP1 expression was highest in the T2D patients with high HbA1c and lowest in the ND group; there was no significant difference between T2D with $\mathrm{HbA} 1 \mathrm{c}<6.0 \%$ ( $42 \mathrm{mmol} / \mathrm{mol}$ ) and ND. These observations suggest that elevated islet SPP1 expression is highly associated with increased glucose levels in humans.

\subsection{OPN increased insulin secretion and cell metabolic activity from human diabetic islets}

To examine the role of OPN on insulin secretion, we incubated human islets from diabetic and non-diabetic donors at 5 and $16.7 \mathrm{mM}$ glucose, in the presence or absence of OPN (Fig. 4). OPN doubled glucose-stimulated insulin secretion (GSIS) in diabetic human islets at high glucose (Fig. 4A), but had no effect on GSIS in non-diabetic islets (Fig. 4B). The stimulatory effect of OPN on insulin secretion in diabetic islets is $\mathrm{Ca}^{2+}$-dependent, which was confirmed using the $\mathrm{Ca}^{2+}$ channel blocker isradipine that abolished the effect of OPN (Fig. 4A).

We also measured human islet cell metabolic activity by MTS assay in the presence of OPN. High glucose $(20 \mathrm{mM})$ decreased cell metabolic activity in both diabetic and non-diabetic islet cells, which was completely reversed by co-incubation with OPN (Fig. 4C).

\section{Discussion}

In this study we present evidence that OPN secretion from the mouse islets is increased by glucose with additive stimulation by 


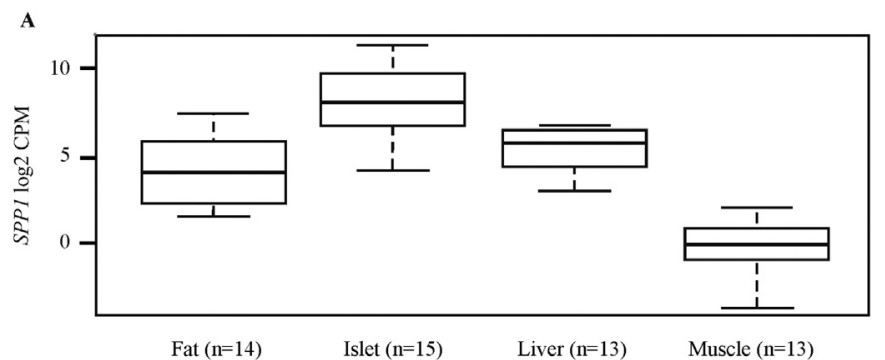

B

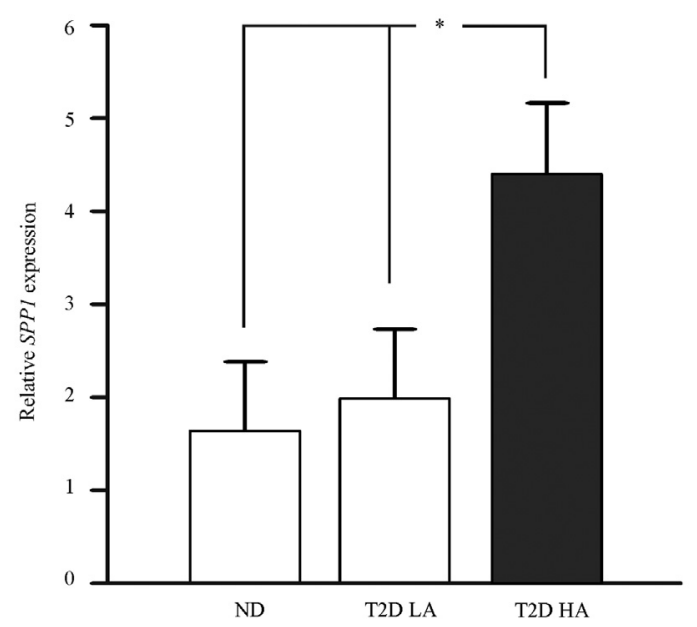

Fig. 3. OPN (SPP1) gene expression in human islets. (A) SPP1 expression was quantified by RNA sequencing in fat $(n=14)$, islets $(n=15)$, liver $(n=13)$ and muscles $(n=13)$ from cadaver donors. (B) SPP1 gene expression was analyzed by quantitative PCR from normal glycemic non-diabetics donors (ND, HbA1c $=4.3-6.0 \%<23-42 \mathrm{mmol} / \mathrm{mol}>$, $\mathrm{n}=7$ ); normal glycemic type 2 diabetics donors (T2DLA, $\mathrm{HbA} 1 \mathrm{c}=4.3-6.0 \%<23-42 \mathrm{mmol} / \mathrm{mol}>, \mathrm{n}=6$ ), or hyperglycemic T2D donors (T2DHA, $\mathrm{HbA} 1 \mathrm{c}>6.5 \%<48 \mathrm{mmol} / \mathrm{mol}>, \mathrm{n}=9$ ). ${ }^{*} p<0.05$ vs. ND normal glycemic donors.

incretins. In both humans and mice, elevated OPN gene expression was strongly associated with diabetic state. We observed that the stimulatory effect of OPN on glucose-stimulated insulin secretion (GSIS) was seen only in T2D human islets but no effect in islets from non-diabetic donors. We also confirmed the protective effect of OPN in promoting human islet cell metabolic activity when challenged by high glucose.

In our study, we chose to use the SUR1-E1506K $+/+$ mouse model, which mimics the human mutation in the $\mathrm{K}_{\mathrm{ATP}}$ channels that leads to congenital hyperinsulinism of infancy, and reduced insulin secretion and diabetes later in life [14]. This animal model is unique in the way that the insulin secretion coupling pathway in the beta cells is disturbed, which consequently leads to diabetes in the animal. This allows us to focus on the effects of beta cell dysfunction-induced hyperglycemia, rather than acute and extreme beta cell loss in the STZ-rat, or monogenic obesity-induced diabetes in the $\mathrm{db} / \mathrm{db}$ mice which involves not only hyperglycemia but also dyslipidemia.

In the islets of diabetic mouse model SUR1-E1506K+/+, we observed a 3 -fold increase in OPN secretion (Fig. 1C); and a 5-fold increase in OPN (Spp1) gene expression (Fig. 1D). The difference in protein and gene expression increases may be due to posttranslational modifications of the gene. OPN is encoded by a single copy gene, but exists in the form of three splice variants: the full-length isoform OPN a, OPN b which lacks exon 5, and OPN c which lacks exon 4 [17]. In gene expression analysis, the TaqMan assay that we used covers Spp1exon 5 to 8 . The ELISA kit that we
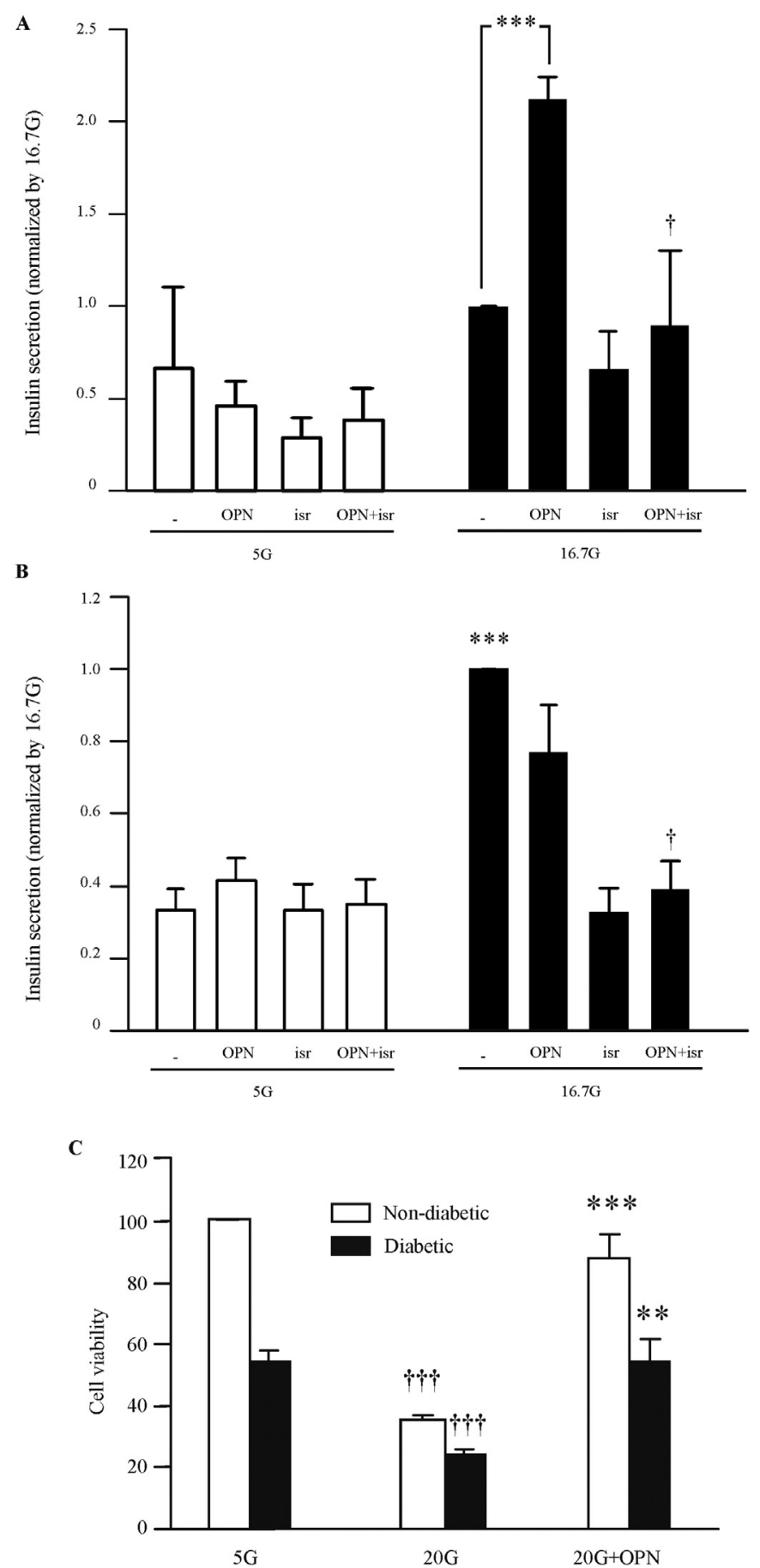

Fig. 4. Effects of OPN on insulin secretion and cell metabolic activity from human islets. $(A-B)$ Insulin secretion was measured from isolated human islets from diabetic donors $(A, n=4-5)$ and non-diabetic donors $(B, n=5)$ at $5 \mathrm{mM}$ glucose $(5 G)$ or $16.7 \mathrm{mM}$ glucose $(16.7 \mathrm{G})$, in the presence of OPN $(200 \mathrm{ng} / \mathrm{ml})$, isradipine (isr, $400 \mu \mathrm{M})$, or simultaneous presence of OPN and isradipine. ${ }^{* * *} p<0.001$ vs. $1 \mathrm{G}$ or indicated; $\dagger p<0.05$ vs. $16.7 \mathrm{G}+$ OPN. (C) Human islets from both non-diabetic (open bars, $\mathrm{n}=6-9$ ) and diabetic (closed bars, $\mathrm{n}=3$ ) were incubated in either $5.5 \mathrm{mM}$ glucose $(5.5 \mathrm{G})$ or $20 \mathrm{mM}$ glucose (20G) in the presence or absence of OPN $(200 \mathrm{ng} / \mathrm{ml})$ for $72 \mathrm{~h}$. Cell metabolic activity was then measured by MTS assay. Three to eight measurements were performed in each experiment for each donor. The values are mean \pm SEM. $\dagger \dagger \dagger p<0.001$ vs. respective 5.5G; ${ }^{* *} p<0.01$ and ${ }^{* * *} p<0.001$ vs. respective $20 \mathrm{G}$.

used for OPN secretion measurements uses antibody binds to the aspartate domain of OPN which is encoded by exon 1. Therefore, one likely explanation for the observed difference in OPN mRNA 
and protein expression is that in gene expression assay we detected OPN a and c gene expression, while in ELISA assay we measured all three possible splice variants. Furthermore, islet OPN mRNA may produce both intracellular and secreted proteins, while ELISA detected only OPN protein secreted from the islets in the medium.

It has also been suggested that intracellular OPN (iOPN) has biological functions distinct from those of secreted OPN (sOPN) $[18,19]$. Here we investigated how OPN secretion is regulated in the islets, and the effects of extracellularly added OPN on islet function. Previous clinical investigations found elevated circulating OPN levels in patients with obesity, which were further increased in obese diabetic or insulin resistant patients [20,21]. Nevertheless, studies of adipose tissue from subjects with obesity revealed no secretion of OPN by adipose tissue [22]. We here provide clear evidence that OPN is secreted from pancreatic islets, which was elevated in diabetic islets, supporting the possibility that OPN secretion is involved in islet protection against hyperglycemia.

Increased OPN gene expression may be a consequence of the progressing diabetic state with decreasing insulin and increasing glucose, and that elevated OPN gene expression may serve as a compensatory mechanism to protect islets from the toxic effects of hyperglycemia. This view was further supported by our observation that OPN was only able to increase GSIS in diabetic islets in humans, but had no effect in non-diabetic islets (Fig. 4). Similar observation in streptozotocin (STZ)-treated mice showed increased serum OPN, and pancreatic OPN mRNA and protein levels [10]. Another study using OPN knock out mice described that mice lacking OPN had lower serum insulin levels when challenged by high blood glucose levels induced by high fat diet [23].

We also observed that elevation of GSIS by OPN in human diabetic islets is $\mathrm{Ca}^{2+}$-dependent (Fig. 4A). OPN induced transient elevations in cytosolic $\mathrm{Ca}^{2+}$ in osteoclasts [24]; and active integrin binding has been shown to induce calcium influx through L-type calcium channel [25-28]. We speculated that similar mechanisms operate in pancreatic beta cells, which were confirmed by demonstrating that OPN-stimulated insulin secretion was abolished by a $\mathrm{Ca}^{2+-}$-channel blocker isradipine.

Taken together, our study clearly demonstrates that glucose and incretins stimulated OPN gene and protein expression in both mouse and human pancreatic islets. Human pancreatic islets from diabetic donors exposed to OPN were able to increase GSIS, thereby creating conditions which might protect islet cells from the toxic effects of high glucose. Given that the effect of OPN on insulin secretion could be abolished by blocking $\mathrm{Ca}^{2+}$ - channels, these observations may point to novel therapeutic targets for islet protection in T2D.

\section{Disclosure statement}

The authors have nothing to disclose.

\section{Conflicts of interest}

The authors declare no conflict of interest.

\section{Funding}

This study was supported by the Swedish Research Council project grant (2010-3490), Linnaeus Centre of Excellence grant (LUDC; 2008-6589) and a Strategic Research Area grant (EXODIAB; 2009-1039) to LG, as well as a project grant (2009-4255) to AS; the European Research Council Advanced Researcher Grant (GENE TARGET T2D, GA269045) to LG; a Diabetes Wellness grant to AS; Bo and Kerstin Hjelt Diabetes Foundation Research Grant to MC; Academy of Finland FiDiPro grant (2634019 and project grant
267882) to LG; the Sigrid Juselius Foundation, Finland to LG; a collaboration grant with Pfizer Inc.

\section{Acknowledgments}

MC, PB, AS, JA, RP and DA performed experiments and data analysis; ML provided the SUR1-E1506K+/+ mouse model; LG designed and supervised all parts of the study and drafted the report; YDM performed experiments and data analysis; designed all parts of the study and drafted the report. YDM and LG are the guarantors of this work and have full access to all the data in the study and take responsibility for the integrity of the data and the accuracy of the data analysis. All researchers took part in the revision of the report and approved the final version.

All authors thank Britt-Marie Nilsson (Department of Clinical Sciences, Islet cell exocytosis, University Hospital Malmö, Malmö, Sweden) for skillful technical assistance.

\section{References}

[1] L.F. Brown, B. Berse, L. Van de Water, A. Papadopoulos-Sergiou, C.A. Perruzzi, E.J. Manseau, H.F. Dvorak, D.R. Senger, Expression and distribution of osteopontin in human tissues: widespread association with luminal epithelial surfaces, Mol. Biol. Cell 3 (1992) 1169-1180.

[2] C. Hao, Y. Cui, S. Owen, W. Li, S. Cheng, W.G. Jiang, Human osteopontin: potential clinical applications in cancer (Review), Int. J. Mol. Med. 39 (2017) 1327-1337.

[3] C. De Fusco, A. Messina, V. Monda, E. Viggiano, F. Moscatelli, A. Valenzano, T. Esposito, C. Sergio, G. Cibelli, M. Monda, G. Messina, Osteopontin: relation between adipose tissue and bone homeostasis, Stem Cells Int. 2017 (2017) 4045238.

[4] T. Wolak, Osteopontin - a multi-modal marker and mediator in atherosclerotic vascular disease, Atherosclerosis 236 (2014) 327-337.

[5] S. Kase, M. Yokoi, W. Saito, N. Furudate, K. Ohgami, M. Kitamura, N. Kitaichi, K. Yoshida, M. Kase, S. Ohno, T. Uede, Increased osteopontin levels in the vitreous of patients with diabetic retinopathy, Ophthalmic Res. 39 (2007) $143-147$.

[6] H. Yamaguchi, M. Igarashi, A. Hirata, H. Tsuchiya, K. Sugiyama, Y. Morita Y. Jimbu, H. Ohnuma, M. Daimon, M. Tominaga, T. Kato, Progression of diabetic nephropathy enhances the plasma osteopontin level in type 2 diabetic patients, Endocr. J. 51 (2004) 499-504.

[7] F. Kahles, H.M. Findeisen, D. Bruemmer, Osteopontin: a novel regulator at the cross roads of inflammation, obesity and diabetes, Mol. Metab. 3 (2014) 384-393.

[8] E. Ahlqvist, P. Osmark, T. Kuulasmaa, K. Pilgaard, B. Omar, C. Brons, O. Kotova, A.V. Zetterqvist, A. Stancakova, A. Jonsson, O. Hansson, J. Kuusisto, T.J. Kieffer, T. Tuomi, B. Isomaa, S. Madsbad, M.F. Gomez, P. Poulsen, M. Laakso E. Degerman, J. Pihlajamaki, N. Wierup, A. Vaag, L. Groop, V. Lyssenko, Link between GIP and osteopontin in adipose tissue and insulin resistance, Diabetes 62 (2013) 2088-2094.

[9] H.A. Arafat, A.K. Katakam, G. Chipitsyna, Q. Gong, A.R. Vancha, J. Gabbeta, D.C. Dafoe, Osteopontin protects the islets and beta-cells from interleukin-1 beta-mediated cytotoxicity through negative feedback regulation of nitric oxide, Endocrinology 148 (2007) 575-584.

[10] A.K. Katakam, G. Chipitsyna, O. Gong, A.R. Vancha, J. Gabbeta, H.A. Arafat, Streptozotocin (STZ) mediates acute upregulation of serum and pancreatic osteopontin (OPN): a novel islet-protective effect of OPN through inhibition of STZ-induced nitric oxide production, J. Endocrinol. 187 (2005) 237-247.

[11] V. Lyssenko, L. Eliasson, O. Kotova, K. Pilgaard, N. Wierup, A. Salehi, A. Wendt, A. Jonsson, Y.Z. De Marinis, L.M. Berglund, J. Taneera, A. Balhuizen, O. Hansson, P. Osmark, P. Duner, C. Brons, A. Stancakova, J. Kuusisto, M. Bugliani, R. Saxena, E. Ahlqvist, T.J. Kieffer, T. Tuomi, B. Isomaa, O. Melander, E. Sonestedt, M. Orho-Melander, P. Nilsson, S. Bonetti, R. Bonadonna, R. Miccoli, S. Delprato, P. Marchetti, S. Madsbad, P. Poulsen, A. Vaag, M. Laakso, M.F. Gomez, L. Groop, Pleiotropic effects of GIP on islet function involve osteopontin, Diabetes 60 (2011) 2424-2433.

[12] K. Shimomura, M. Tusa, M. Iberl, M.F. Brereton, S. Kaizik, P. Proks, C. Lahmann, N. Yaluri, S. Modi, H. Huopio, J. Ustinov, T. Otonkoski, M. Laakso, F.M. Ashcroft A mouse model of human hyperinsulinism produced by the E1506K mutation in the sulphonylurea receptor SUR1, Diabetes 62 (2013) 3797-3806.

[13] H. Huopio, F. Reimann, R. Ashfield, J. Komulainen, H.L. Lenko, J. Rahier, I. Vauhkonen, J. Kere, M. Laakso, F. Ashcroft, T. Otonkoski, Dominantly inherited hyperinsulinism caused by a mutation in the sulfonylurea receptor type 1, J. Clin. Investig. 106 (2000) 897-906.

[14] H. Huopio, T. Otonkoski, I. Vauhkonen, F. Reimann, F.M. Ashcroft, M. Laakso, A new subtype of autosomal dominant diabetes attributable to a mutation in the gene for sulfonylurea receptor 1, Lancet 361 (2003) 301-307.

[15] Y. De Marinis, M. Cai, P. Bompada, D. Atac, O. Kotova, M.E. Johansson, E. Garcia-Vaz, M.F. Gomez, M. Laakso, L. Groop, Epigenetic regulation of the 
thioredoxin-interacting protein (TXNIP) gene by hyperglycemia in kidney, Kidney Int. 89 (2016) 342-353.

[16] M. Cai, P. Bompada, D. Atac, M. Laakso, L. Groop, Y. De Marinis, Epigenetic regulation of glucose-stimulated osteopontin (OPN) expression in diabetic kidney, Biochem. Biophys. Res. Commun. 469 (2016) 108-113.

[17] E.R. Gimba, T.M. Tilli, Human osteopontin splicing isoforms: known roles, potential clinical applications and activated signaling pathways, Cancer Lett. 331 (2013) 11-17.

[18] A. Junaid, M.C. Moon, G.E. Harding, P. Zahradka, Osteopontin localizes to the nucleus of 293 cells and associates with polo-like kinase-1, Am. J. Physiol. Cell Physiol. 292 (2007) C919-C926.

[19] M. Inoue, M.L. Shinohara, Intracellular osteopontin (iOPN) and immunity, Immunol. Res. 49 (2011) 160-172.

[20] J. Gomez-Ambrosi, V. Catalan, B. Ramirez, A. Rodriguez, I. Colina, C. Silva, F. Rotellar, C. Mugueta, M.J. Gil, J.A. Cienfuegos, J. Salvador, G. Fruhbeck, Plasma osteopontin levels and expression in adipose tissue are increased in obesity, J. Clin. Endocrinol. Metab. 92 (2007) 3719-3727.

[21] R. Ahmad, A. Al-Mass, D. Al-Ghawas, N. Shareif, N. Zghoul, M. Melhem, A. Hasan, F. Al-Ghimlas, S. Dermime, K. Behbehani, Interaction of osteopontin with IL-18 in obese individuals: implications for insulin resistance, PLoS One 8 (2013) e63944.

[22] A. Bertola, V. Deveaux, S. Bonnafous, D. Rousseau, R. Anty, A. Wakkach, M. Dahman, J. Tordjman, K. Clement, S.E. McQuaid, K.N. Frayn, P.M. Huet, J. Gugenheim, S. Lotersztajn, Y. Le Marchand-Brustel, A. Tran, P. Gual, Elevated expression of osteopontin may be related to adipose tissue macrophage accumulation and liver steatosis in morbid obesity, Diabetes 58 (2009) 125-133.

[23] A. Lancha, A. Rodriguez, V. Catalan, S. Becerril, N. Sainz, B. Ramirez, M.A. Burrell, J. Salvador, G. Fruhbeck, J. Gomez-Ambrosi, Osteopontin deletion prevents the development of obesity and hepatic steatosis via impaired adipose tissue matrix remodeling and reduced inflammation and fibrosis in adipose tissue and liver in mice, PLoS One 9 (2014) e98398.

[24] N. Tanabe, B.D. Wheal, J. Kwon, H.H. Chen, R.P. Shugg, S.M. Sims, H.A. Goldberg, S.J. Dixon, Osteopontin signals through calcium and nuclear factor of activated T cells (NFAT) in osteoclasts: a novel RGD-dependent pathway promoting cell survival, J. Biol. Chem. 286 (2011) 39871-39881.

[25] L. Balasubramanian, A. Ahmed, C.M. Lo, J.S. Sham, K.P. Yip, Integrin-mediated mechanotransduction in renal vascular smooth muscle cells: activation of calcium sparks, Am. J. Physiol. Regul. Integr. Comp. Physiol. 293 (2007) R1586-R1594.

[26] W.L. Chan, N.H. Holstein-Rathlou, K.P. Yip, Integrin mobilizes intracellular $\mathrm{Ca}(2+)$ in renal vascular smooth muscle cells, Am. J. Physiol. Cell Physiol. 280 (2001) C593-C603.

[27] A. Umesh, M.A. Thompson, E.N. Chini, K.P. Yip, J.S. Sham, Integrin ligands mobilize $\mathrm{Ca} 2+$ from ryanodine receptor-gated stores and lysosome-related acidic organelles in pulmonary arterial smooth muscle cells, J. Biol. Chem. 281 (2006) 34312-34323.

[28] X. Wu, G.E. Davis, G.A. Meininger, E. Wilson, M.J. Davis, Regulation of the Ltype calcium channel by alpha 5beta 1 integrin requires signaling between focal adhesion proteins, J. Biol. Chem. 276 (2001) 30285-30292. 